\title{
TRACER TEST ON THE MALA GORA LANDFILL NEAR RIBNICA IN SOUTH-EASTERN SLOVENIA
}

\author{
SLEDILNI POSKUS NA ODLAGALIŠČU MALA GORA \\ PRI RIBNICI V JUGOVZHODNI SLOVENIJI
}

\author{
Janja KOGOVŠEK ${ }^{1} \&$ Metka PETRIČ $^{1}$
}

\begin{abstract}
UDC 556.3:504.054(497.4-12)

Janja Kogovšek \& Metka Petrič: Tracer test on the Mala gora landfill near Ribnica in south-eastern Slovenia

The Mala gora landfill near Ribnica is one of the nine still active landfills on Slovene karst. According to our legislation the monitoring of its impact on groundwater have to be performed, but this can only be effective when the characteristics of the underground water flow in the area of the landfill are well known. Therefore a tracer test was carried out on the Mala gora landfill and the main underground water connections towards the Tominčev studenec, Javornikov izvir, Debeljakov izvir and Šica springs near the settlement Dvor in the Krka valley were proved. In lower concentrations the uranine was detected in the Podpeška jama and Kompoljska jama Caves, as well as in the Šica near Mala Račna spring and both springs of the Krka river. At high waters the flow from the landfill towards the Globočec spring was proved also, but this important source of water supply is primary recharged from other parts of the karst aquifer. The appearance of tracer is forwarded by favourable hydrological conditions and increased concentrations of uranine were measured at all springs after more intensive precipitation events even one year after the injection. Obtained results were considered in the preparation of the monitoring plan.

Key words: tracer test, landfill, Mala gora, Slovenia.
\end{abstract}

Izvleček UDK 556.3:504.054(497.4-12)

Janja Kogovšek \& Metka Petrič: Sledilni poskus na odlagališču Mala gora pri Ribnici v jugovzhodni Sloveniji

Odlagališče komunalnih odpadkov Mala gora pri Ribnici je eno izmed devetih trenutno še aktivnih odlagališč na slovenskem krasu. Skladno z zakonodajo je potrebno izvajati monitoring njegovega vpliva na podzemne vode, ki pa je lahko učinkovit le ob dobrem poznavanju značilnosti pretakanja podzemnih vod na območju odlagališča. Zato smo izvedli sledilni poskus, ki je pokazal, da je glavna smer odtekanja podzemne vode $\mathrm{z}$ območja Male gore proti izvirom Tominčev studenec, Javornikov izvir, Debeljakov izvir in Šica pri naselju Dvor v dolini Krke. V manjših koncentracijah se je uranin pojavil v Podpeški in Kompoljski jami, dokazano pa je bilo tudi sekundarno odtekanje proti Šici pri Mali Račni in izviroma reke Krke. Ob višjih vodostajih podzemne vode $\mathrm{z}$ območja odlagališča odtekajo tudi proti izviru Globočec, vendar pa se ta pomemben vir za vodooskrbo primarno napaja iz drugih delov kraškega vodonosnika. Pojavljanje sledila je vezano na ugodne hidrološke razmere in povečane koncentracije uranina so bile po močnejših padavinah zabeležene $\mathrm{v}$ vseh izvirih še eno leto po injiciranju. Zbrane ugotovitve smo upoštevali pri pripravi programa monitoringa.

Ključne besede: sledilni poskus, odlagališče odpadkov, Mala gora, Slovenija.

\section{INTRODUCTION}

Several tracer tests have been performed recently in Slovenia on landfills on karst with the aim to better understand the directions and characteristics of groundwater flow from these sources of pollution and to prepare an efficient plan for the monitoring of groundwater in the area of influence of the landfill. In the article the results of tracing at the Mala gora landfill near Ribnica in south-eastern Slovenia are presented. In this area several

${ }^{1}$ Karst Research Institute ZRC SAZU, Titov trg 2, SI-6230 Postojna, Slovenija,

e-mail: kogovsek@zrc-sazu.si, petric@zrc-sazu.si

Received / Prejeto: 19.09.2006 
tracer tests were carried out in the past, but in all cases the tracers were injected into a sinking stream or into a water flow in a cave. This means direct input into the main drainage channels and therefore fast flow towards the karst springs. But for the landfills a diffuse infiltration of precipitation and harmful substances dissolved in it into the upper vadose zone of karst aquifers is characteristic. In the area of the Mala gora landfill the depth of the vadose zone is estimated to approximately $100 \mathrm{~m}$ (Kogovšek et al., 2005) and the flow through it can significantly influence the transport of these substances. To test this influence it was decided to inject the tracer on the surface. And to simulate more dangerous and harmful conditions tracing was performed at high waters and the tracer was injected in a well permeable fissure at the border of the landfill.

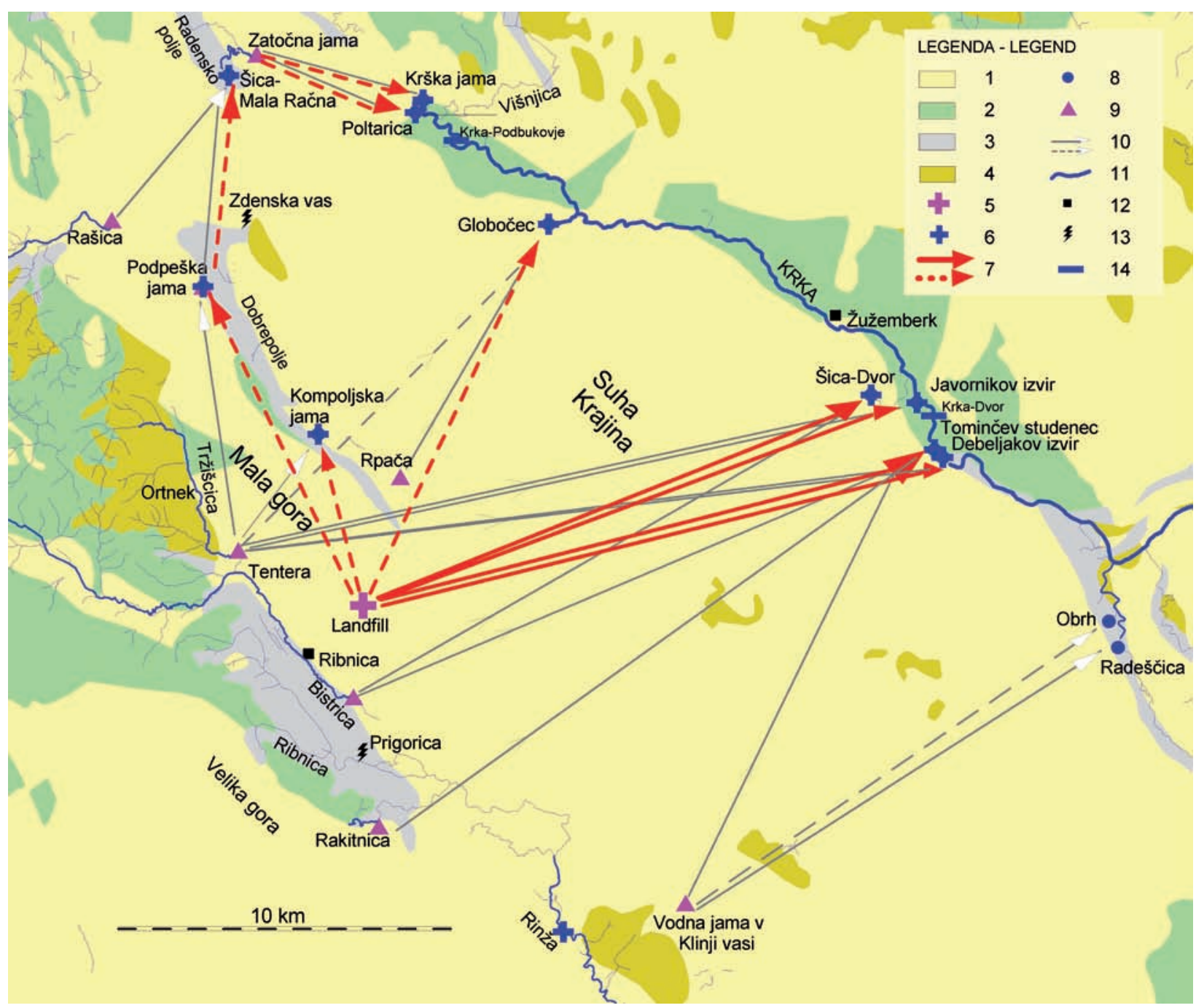

Fig. 1. Hydrogeological map of the broader area of the Mala gora landfill with the results of tracer tests (1. Karst aquifer, 2. Fissured aquifer, 3. Porous aquifer, 4. Very low permeable rocks, 5. Landfill Mala gora - injection point at the tracer test in October 2004, 6. Sampling point at the tracer test in October 2004, 7. Main and secondary groundwater connection proved by tracer test in October 2004, 8. Spring, 9. Injection point at previous tracings, 10. Main and secondary groundwater connections proved by previous tracings, 11. Surface flow, 12. Settlement, 13. Precipitation station, 14. Gauging station).

Sl. 1. Hidrogeološka karta širšega območja deponije Mala gora zrezultati sledilnih poskusov (Legenda: 1. kraški vodonosnik, 2. razpoklinski vodonosnik, 3. medzrnski vodonosnik, 4. zelo slabo prepustne kamnine, 5. deponija »Mala gora« - točka injiciranja sledila ob sledenju $v$ oktobru 2004, 6. točka zajemanja vzorcev ob sledenju oktobra 2004, 7. s sledenjem oktobra 2004 dokazana glavna in stranska smer podzemnega pretakanja, 8. izvir, 9. točka injiciranja sledila pri starejših sledenjih, 10. glavna in stranska smer podzemnega pretakanja, ugotovljena pri starejših sledenjih, 11. površinski tok, 12. naselje, 13. padavinska postaja, 14. hidrološka postaja). 


\section{HYDROGEOLOGICAL CHARACTERISTICS}

In a broader sense the area of landfill is a part of the karst plateaux Mala gora and Suha Krajina which are built of well permeable Jurassic and Cretaceous carbonate rocks (Fig. 1). Groundwater flow prevails and the only exception is karst polje Dobrepolje on which Cretaceous limestone and Triassic dolomite are covered with alluvial sediments (Buser 1968). During high waters it is temporary flooded.

Groundwater is drained towards the border of the plateux. On the north-eastern side is the Krka river with two main springs Krška jama and Poltarica. Common mean discharge of both springs is $8.3 \mathrm{~m}^{3} / \mathrm{s}$ (Kolbezen \& Pristov 1998). The Globočec spring is a right tributary near the village Fužina (mean discharge between 1 and $1.5 \mathrm{~m}^{3} / \mathrm{s}$ (Novak 1985)) and is the main source of drinking water for the whole Suha Krajina region (Fig. 2). Along the Krka

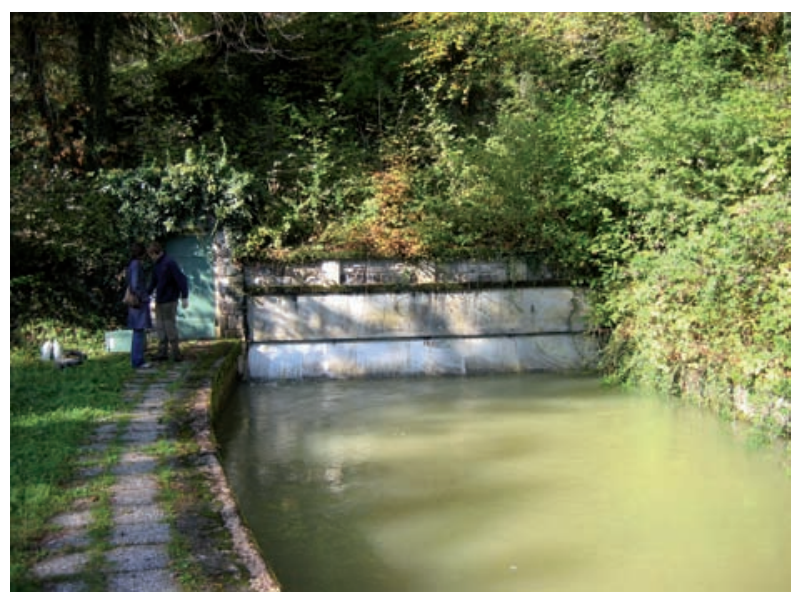

Fig. 2. The Globočec spring is the main source of drinking water for the Suha Krajina region.

Sl. 2. Izvir Globočec je glavni vir za vodooskrbo Suhe Krajine.

riverbed near the settlement Dvor near Žužemberk there are three bigger springs: Tominčev studenec, Debeljakov izvir and Javornikov izvir. The later is active only temporary. The biggest among them is Tominčev studenec (Fig. 3) with the mean discharge of $1.6 \mathrm{~m}^{3} / \mathrm{s}$ (Novak 1987). Higher in the slope is an intermittent spring Šica. After short surface flow it sinks again underground at different points in its riverbed and only at extremely high waters it reaches the Krka river as its surface tributary.

Further towards east is the Radeščica stream which is another important right tributary of the Krka river. It is recharged by several karst springs, the biggest among them are Radeščica and Obrh.

At the south-western side the karst plateaux are bordered by the Ribnica polje with the surface streams
Bistrica, Ribnica and Rakitnica. Bistrica is partly recharged from low permeable Triassic rocks and partly from Triassic dolomite (Buser 1968). The recharge areas of Ribnica and Rakitnica are Upper Triassic, Jurassic and Cretaceous carbonate rocks of the Velika gora hills. All three surface streams sink at the south-eastern border of polje, but at very high waters the surface flow can extend to the Rinža river and sinks at the southern border of the Kočevje polje.

At the western part of the studied area the surface streams Tržiščica and Rašica collect waters from dolomite and non-carbonate rocks of Triassic and Permian age (Buser 1968). Tržiščica sinks at the contact with limestone into the Tentera Cave. Rašica flows further on karst area and sinks then into several ponors near the village of Ponikve. At very high waters their swallow capacity is too low and Rašica flows on the surface towards Dobrepolje. At Dobrepolje some intermittent springs are active after heavy raining, the biggest among them emerge from the Podpeška jama and Kompoljska jama Caves. In both caves the permanent water level is approximately $7 \mathrm{~m}$ below the bottom of the polje during low waters (Kranjc 1981).

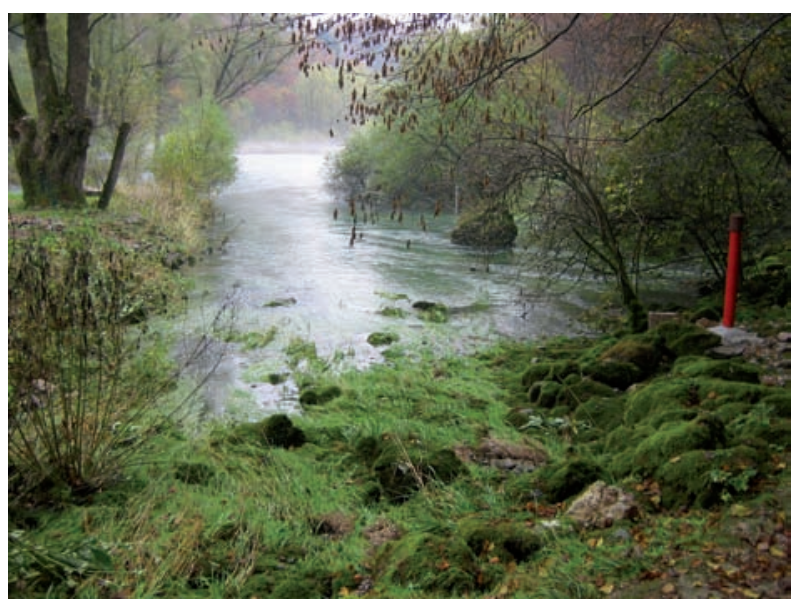

Fig. 3. The Tominčev studenec spring at low waters.

Sl. 3. Izvir Tominčev studenec ob nizkem vodostaju.

The Radensko polje in the north-western side is temporary flooded. Among several springs at its border the Šica spring near Mala Račna is the most important. The springs recharge surface streams which sink into the ponors at the other side of the polje. Šica flows into the Zatočna jama Cave. 


\section{PREVIOUS TRACER TESTS}

To define the directions and characteristics of groundwater flow in the broader studied area several tracer tests were performed in the past (Fig. 1). Three times the Tržiščica stream at the ponor into the Tentera Cave was traced. During high waters in 1912 one kilogram of uranine was injected and the underground water connection with the Kompoljska jama Cave was proved (Šerko 1946). The springs in the Krka valley were not observed. During low waters in May 1984 uranine was used again (Novak 1985). Surprisingly fast the tracer was detected in the Podpeška jama Cave and in the Poltarica spring (probably indirectly by Šica near Mala Račna). The highest concentrations of uranine were measured at Šica near Dvor, Tominčev studenec and Debeljakov izvir, and in the Globočec spring the tracer was detected also. Apparent flow velocity towards Tominčev studenec was estimated to $10.2 \mathrm{~cm} / \mathrm{s}$ and towards Globočec to $5.4 \mathrm{~cm} / \mathrm{s}$. As the sampling was not fully reliably it was suggested to verify the connections between Tržiščica and Podpeška jama Cave, Poltarica and Globočec (Novak 1987).

New information regarding the characteristics of underground water connections was obtained in October 1998. An accident at the petrochemical depot in Ortnek resulted in an unknown quantity of gas oil entering the Tržiščica stream (Genorio 1999). It was detected in Globočec after 8 days in concentration $0.013 \mathrm{mg} / \mathrm{l}$. Based on these data the apparent flow velocity would be $3 \mathrm{~cm} /$ $\mathrm{s}$, but already after 8 hours the concentration dropped below $0.005 \mathrm{mg} / \mathrm{l}$ (upper limit for drinking water is 0.01 $\mathrm{mg} / \mathrm{l}$ ) and only a typical odour was present. Allowed concentration was exceeded again only in May 1999 after heavy rain.

The third tracing of Tržiščica with $4.6 \mathrm{~kg}$ of uranine was carried out in April 2000 at medium to low recession conditions (Kogovšek \& Petrič 2002, Kogovšek \& Petrič 2004). The most rapid flow towards the Tominčev studenec $\left(\mathrm{v}_{\text {dom }}=4.6 \mathrm{~cm} / \mathrm{s}\right)$, and somewhat slower flow towards the Javornikov izvir and Debeljakov izvir were proved by the results. In two months approximately $2 / 3$ of the total amount of injected tracer was recovered at these springs. After heavy rain at the end of the two months period of recession, lower concentrations of the tracer were detected also in the Podpeška jama Cave. In the Globočec spring in which the sampling was most frequent the tracer did not appear. So in the described conditions the expected connection with this spring was not confirmed.

The following underground water connections were also proved by tracer tests: flow from Šica at the ponor into the Zatočna jama Cave towards the springs of the Krka river in 1934 (Šerko 1946), from the Rašica sinking stream towards the Šica near Mala Račna and two springs of the Krka river (Poltarica and Krška jama) in 1966 (Habič et al., 1993), from the Podpeška jama Cave towards the Šica near Mala Račna and two springs of the Krka river in April 1982 (Novak 1985), from the sinking stream Rpača towards the Globočec spring in April 1987 (Grm \& Novak 1989), from the Bistrica sinking stream towards the Tominčev studenec and Šica near Dvor $\left(\mathrm{v}_{\mathrm{dom}}=8.5 \mathrm{~cm} / \mathrm{s}\right)$ in September 1965 (Habič et al., 1993), from the Rakitnica sinking stream towards the Tominčev studenec $\left(\mathrm{v}_{\text {dom }}=3 \mathrm{~cm} / \mathrm{s}\right)$ in July 1955 (Gams 1965), and from the Vodna jama $\mathrm{v}$ Klinji vasi Cave towards the Tominčev studenec $\left(\mathrm{v}_{\mathrm{dom}}=6 \mathrm{~cm} / \mathrm{s}\right)$, as well as towards the Radeščica spring near Podturn and probably also towards the nearby Obrh spring (Novak 1987).

In all described tracer tests the tracers were injected into a sinking stream or into a water flow in a cave. This means direct input into the main drainage channels and therefore fast flow towards the karst springs. But for the landfills a diffuse infiltration of precipitation and harmful substances dissolved in it into the upper vadose zone of karst aquifers is characteristic. The flow through it can significantly influence the transport of these substances, therefore to simulate the conditions at the landfill a new tracer test with the injection of tracer at the surface was planned and carried out in October 2004.

\section{TRACER TEST IN OCTOBER 2004}

\section{Precipitation and hydrological conditions in the time of tracing}

The Environmental Agency of the Republic of Slovenia operates with two precipitation stations inside the study area: in Zdenska vas near Dobrepolje and in Prigorica on
Ribnica polje (Fig. 1). For both stations similar precipitation regimes are characteristic and therefore averages of both measured values were used as daily precipitation in further processing of data (Fig. 4).

Discharges of the springs in the impact area of the Mala gora landfill are not regularly measured. Only dis- 
charges of the Krka river are measured by the Environmental Agency and for the time of tracing till the end of May 2005 we obtained data for two gauging stations: Krka-Podbukovje and Krka-Dvor (Fig. 1). The later were used for the estimation of the discharges of Tominčev studenec. Characteristic discharges of this spring were defined by some previous measurements: Qmin $=0.54 \mathrm{~m}^{3} / \mathrm{s}$, Qmean $=1.6 \mathrm{~m}^{3} / \mathrm{s}$ and $\mathrm{Qmax}=10 \mathrm{~m}^{3} / \mathrm{s}$ (Novak 1992), and by comparison with the measured values for Krka-Dvor the daily discharges of Tominčev studenec in the time of tracing were estimated (Fig. 4). Additionally, at Tominčev studenec the pressure probe for measurement of water levels in hourly intervals was operated by the Institute of Mining, Geology and Geotechnology from October 2004 to May 2005, and occasionally the water levels were read also at the staff gauge, which was installed at the spring by the Environmental Agency several years ago. The correlation between measured water levels and estimated discharges was good, so the later were used in further processing of the results of the tracer test.

At the Globočec spring the gauging station for water level measurements is operated by the Environmental Agency and from them we obtained the data for the period from 12 October 2004 to 15 March 2005. As these were only water level data, we used a series of parallel measurements of levels and discharges carried out by the Agency, based on which the relation between both parameters was defined and then used for the estimation of discharges of Globočec spring for the period from October 2004 to March 2005 (Fig. 4). Additionally, the correlation between these data and the measured discharges at Krka-Dvor was set and then used for the estimation of the discharges of Globočec in the period from 16 March to 31 May 2005 (Fig. 4).

The discharge at the gauging station Krka-Podbukovje is composed by flows from the springs Krška jama and Poltarica, and the tributary Višnjica. In the last years no measurements of individual flows were performed, therefore an average share of the Višnjica discharges in the total Krka-Podbukovje discharges was estimated to $6 \%$ based on the comparison of the mean monthly values in the period 1990-2000 (Kolbezen \& Pristov 1998). Taking this into account the common discharge of both Krka springs in the time of tracing was assessed based on measured discharges at Krka-Podbukovje (Fig. 4).

The tracer test was carried out in the period of intensive rain before and after injection of tracer. In September and the first half of October 2004 the total amount of precipitation was $163 \mathrm{~mm}$, then after injection in the second half of October additional $190 \mathrm{~mm}$, and in November and December $218 \mathrm{~mm}$. Also the discharges of observed springs were very high, especially immediately after injection with extreme peaks on 18 October 2004 (Fig. 4).

The beginning of the year 2005 was relatively dry and then from March till the end of May four times a more significant increase of discharges was noted. We were not able to get the data on discharges for the period from June 2005 onwards, so we can only asses the hydrological conditions based on precipitation measurements and compare them with the tracer breakthrough curves.

\section{Injection and sampling}

The landfill is located on well karstified Upper Jurassic limestone, alternating with dolomite and covered with thin, often interrupted layers of brown soil. After testing its swallow capacity, a highly-permeable vertical fissure at the margin of the landfill at the altitude of $570 \mathrm{~m}$ asl was chosen as an injection point for tracer test. After several days of rain, a solution of $7 \mathrm{~kg}$ of uranine was injected into it on 14 October 2004 and washed off with $9 \mathrm{~m}^{3}$ of water (Fig. 5).

The sampling of water was organised at 11 locations (springs, water flow in caves, surface stream). At the Globočec spring an automatic sampler ISCO 6700A was installed. At the beginning of the test the samples were taken each 6 hours, and later once per day. At other points the water samples for measuring the uranine level were collected manually in dark glass bottles. In Tominčev studenec, Debeljakov izvir, Javornikov izvir, and Podpeška jama sampling was organised once per day, occasionally also twice per day. Frequency of sampling in the later period of the test was reduced and adjusted to hydrological conditions. At other points (Kompoljska jama Cave, springs Šica-Dvor, Šica-Mala Račna, Krška jama and Poltarica, and surface stream Rinža) only separate series of samples were taken.

Fluorescence was measured in laboratory by a luminescence spectrometer LS 30, Perkin Elmer $\left(\mathrm{E}_{\mathrm{ex}}=491 \mathrm{~nm}\right.$, $\mathrm{E}_{\mathrm{em}}=512 \mathrm{~nm}$ ) with detection limit of $0.005 \mathrm{ppb}(1 \mathrm{ppb}=1$ $\left.\mathrm{mg} / \mathrm{m}^{3}\right)$. Samples with higher levels of turbidity were initially decanted and filtered $(0.45 \mu \mathrm{m})$.

\section{Results of tracing}

Injected uranine was detected at 10 sampling points, with the exception of the Rinža surface stream (Fig. 1). Already after 5 days and in highest concentrations up to $1.18 \mathrm{ppb}$ the tracer has appeared at Javornikov izvir and Šica near Dvor (Fig. 6). At the same time it was detected in Tominčev studenec in concentrations up to $0.19 \mathrm{ppb}$, and with a short delay also in Debeljakov izvir. In this spring higher concentrations up to $0.08 \mathrm{ppb}$ were measured in the beginning of November 2004 (Fig. 7). 


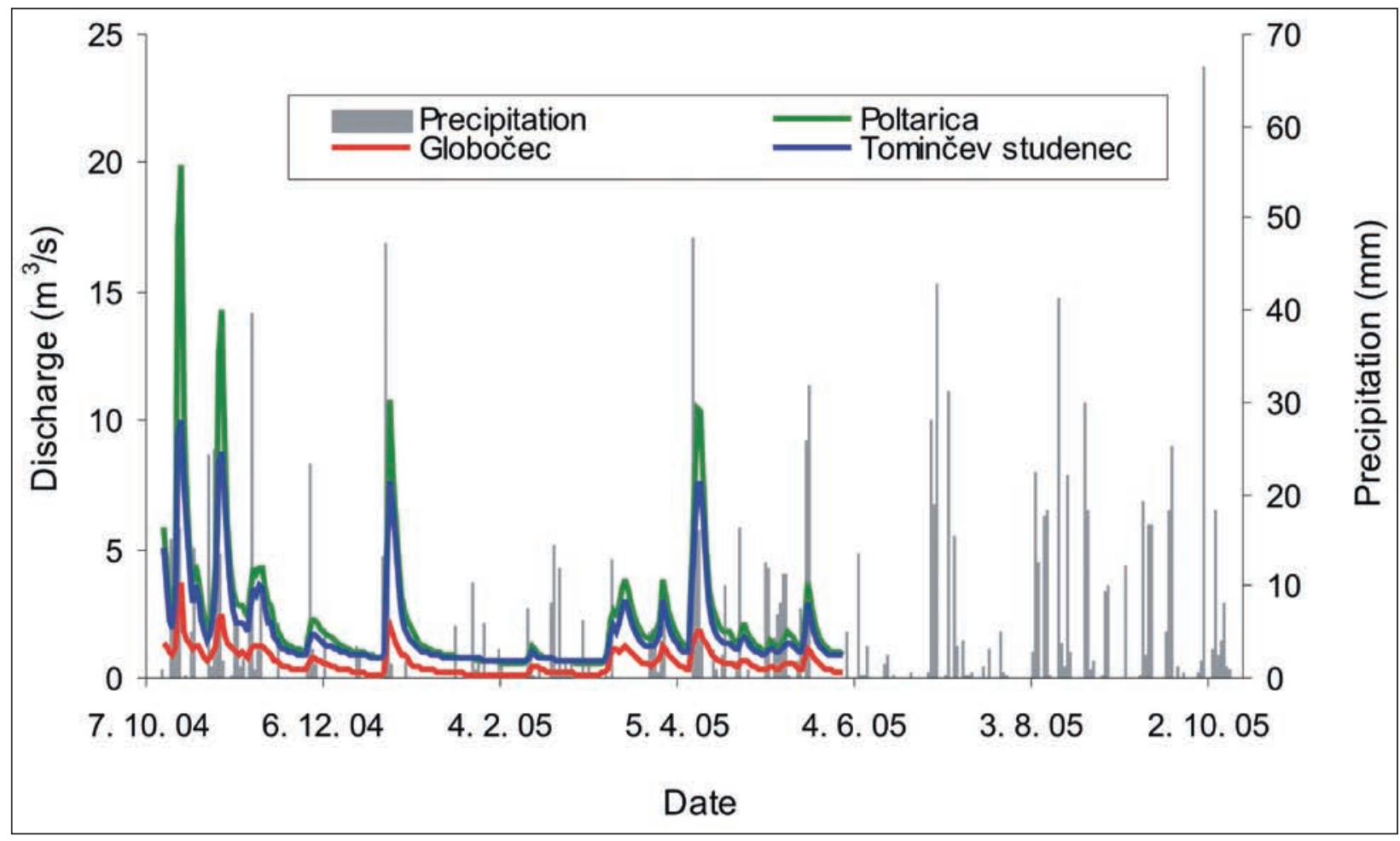

Fig. 4. Precipitation and hydrological conditions in the time of tracing.

Sl. 4. Padavinske in hidrološke razmere v času sledenja.

Strong oscillations of uranine concentrations measured in the Podpeška jama Cave indicate inflows from different parts of the aquifer. First peak appeared already on 17 October 2004, which gives the apparent flow velocity of $4.1 \mathrm{~cm} / \mathrm{s}$, but maximum concentration of 0.135 ppb was detected on 31 October 2004. In the Kompoljska jama Cave the signal was occasionally increased and this

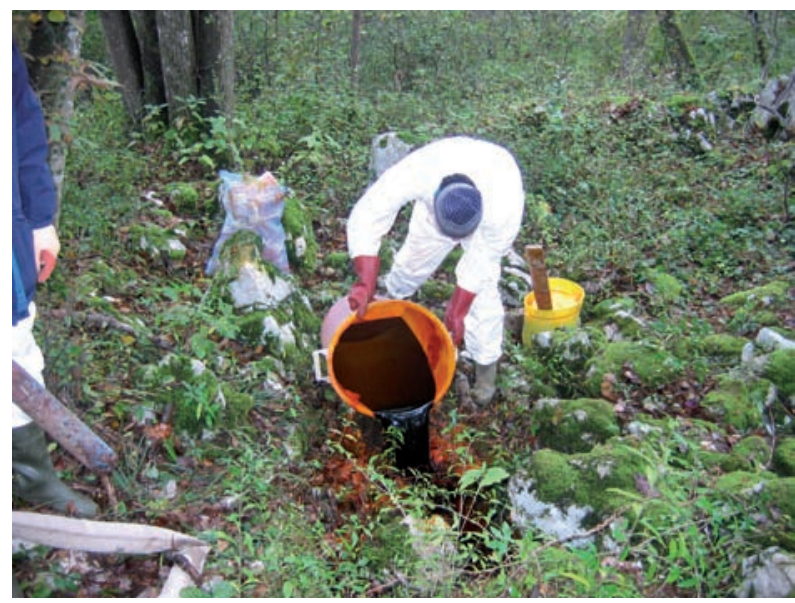

Fig. 5. A solution of uranine was injected into a well permeable fissure at the margin of the landfill.

Sl. 5. Raztopino uranina smo zlili $v$ dobro prepustno razpoko na robu odlagališča. indicates the groundwater connection, but as there only same separate samples were taken, more detailed analysis of this connection is not possible (Fig. 8).

The connections with both springs of the Krka river were confirmed also (Fig. 8). In spite of irregular sampling a significant increase and then decrease of uranine concentrations in the Krška jama can be seen after each precipitation event, although at the beginning of the observation some oscillations were present. They indicate the inflow from an extensive recharge area with different influences. The breakthrough curve of the Poltarica spring has a parallel course but somewhat lower concentrations. By longer duration of sampling a significant signal of tracer was observed at both springs in October 2005.

At the Šica near Mala Račna spring the sampling was irregular also (Fig. 8), but the peaks of concentrations of uranine were detected in comparable times as in both springs of the Krka river. Therefore we can presume that at least one part of the tracer flows indirectly through Dobrepolje and Radensko polje towards the Krka springs. But to get a more precise picture about these connections a more detailed observation at all points in a longer period of at least one year would be necessary.

At all observed springs increased concentrations of uranine were detected after each intensive precipitation 


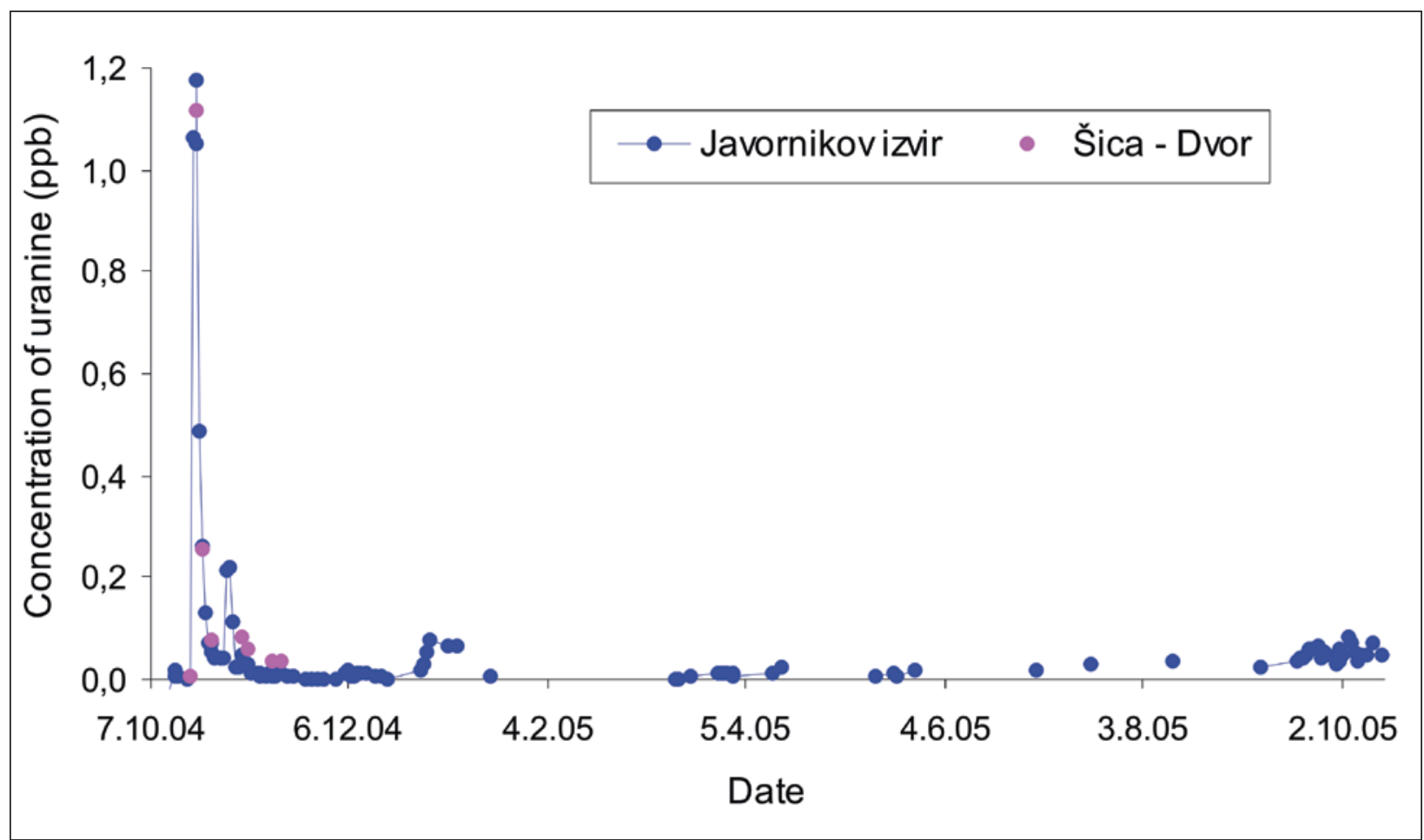

Fig. 6. The highest concentrations of uranine were detected in Javornikov izvir. At Šica near Dvor samples were taken only occasionally and in them similar concentrations of tracer were measured.

Sl. 6. Najvišje koncentracije uranina so bile zabeležene v Javornikovem izviru. V Šici pri Dvoru smo zajemali vzorce le občasno in v njih smo izmerili podobne koncentracije.

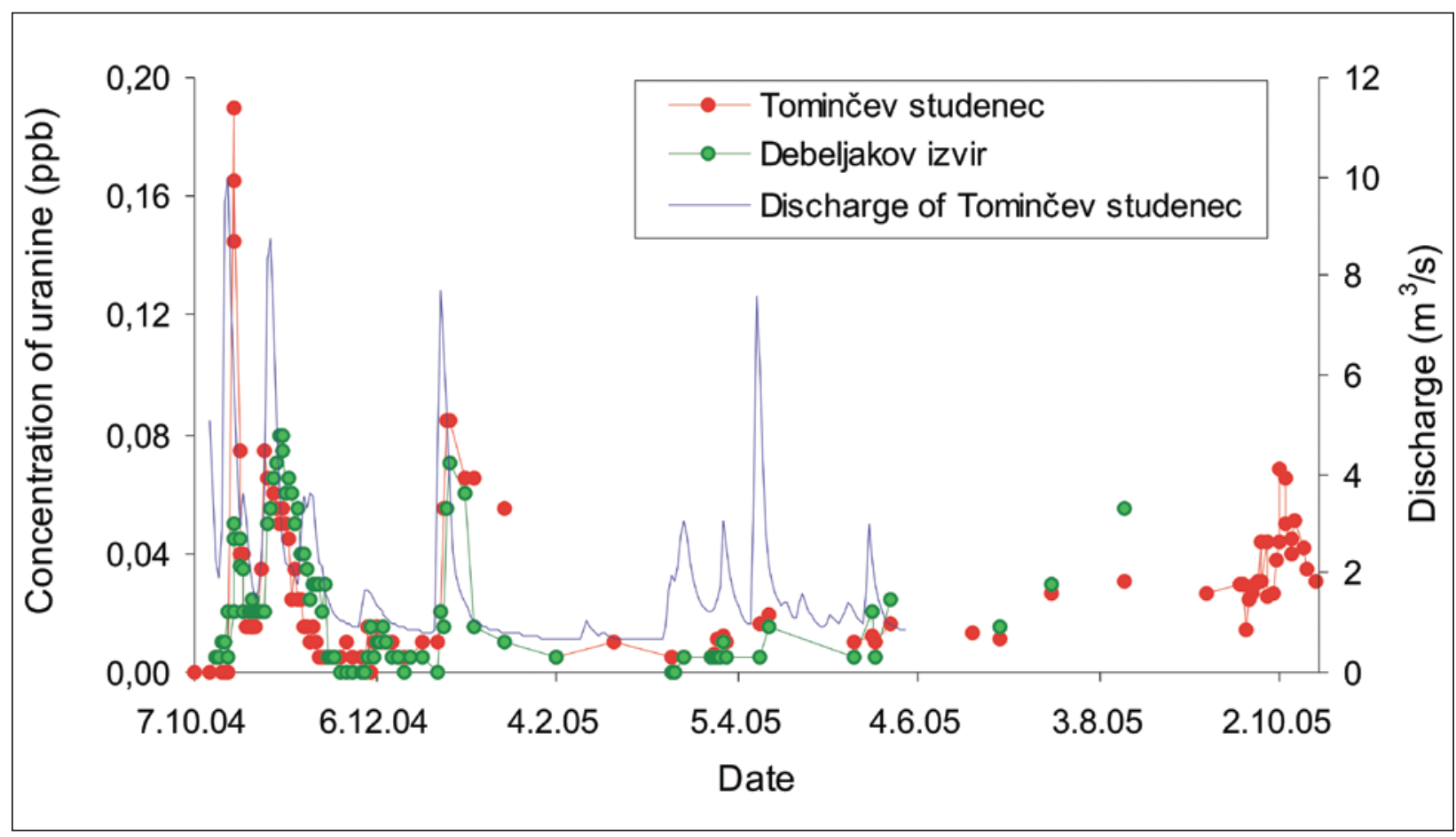

Fig. 7. Concentrations of uranine in the Tominčev studenec and Debeljakov izvir springs, and discharges in Tominčev studenec Sl. 7. Koncentracije uranina $v$ Tominčevem studencu in Debeljakovem izviru ter pretok Tominčevega studenca. 


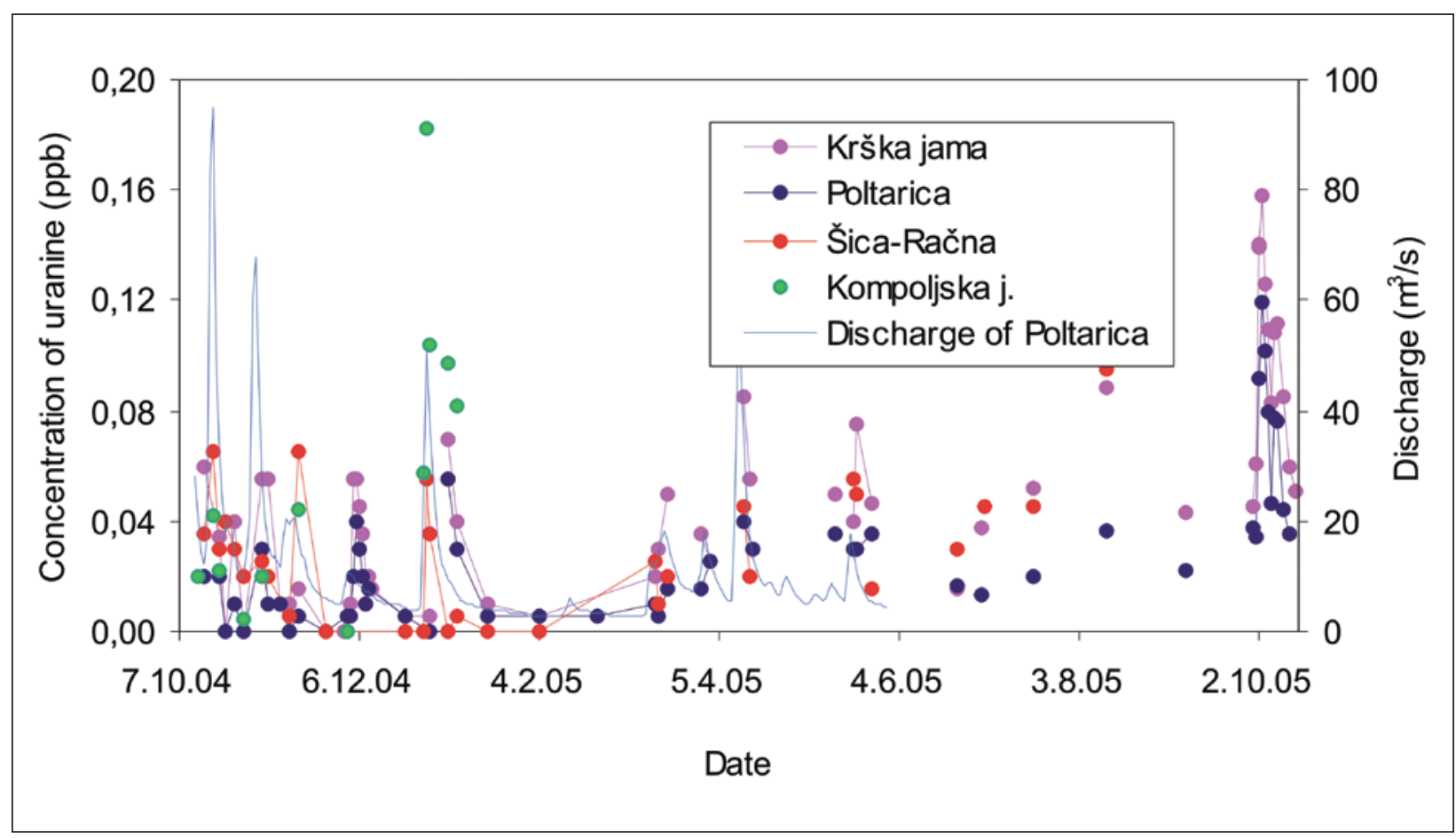

Fig. 8. Uranine breakthrough curves for other springs.

Sl. 8. Krivulje koncentracij uranina za ostale izvire.

event, which washed out the tracer stored in the vadose zone and karst channels. Relatively high concentrations were measured in October 2005 almost one year after the injection of tracer, and such appearances of uranine are to be expected also in the following period.

Table 1. Estimation of apparent dominant velocities of groundwater flow.

Tabela 1. Izračun navideznih dominantnih hitrosti pretakanja podzemnih vod.

\begin{tabular}{|l|c|c|c|c|}
\hline Sampling point & $\begin{array}{c}\text { Height } \\
\text { difference } \\
(\mathrm{m})\end{array}$ & $\begin{array}{c}\text { Distance } \\
(\mathrm{m})\end{array}$ & $\begin{array}{c}\mathrm{t}_{\text {dom }} \\
(\mathrm{h})\end{array}$ & $\begin{array}{c}\mathrm{v}_{\text {dom }} \\
(\mathrm{cm} / \mathrm{s})\end{array}$ \\
\hline Tominčev studenec & 395 & 17800 & 122,5 & 4,0 \\
\hline Debeljakov izvir & 397 & 18045 & 142 & 3,5 \\
\hline Javornikov izvir & 390 & 17710 & 143,5 & 3,4 \\
\hline Šica-Dvor & 370 & 16515 & & 3,4 \\
\hline Globočec & 322 & 12740 & 124,5 & 2,9 \\
\hline
\end{tabular}

Calculated apparent flow velocities are comparable with those estimated at the tracer test with direct injection into the Tržiščica sinking stream during medium water hydrological conditions in April 2000 (Kogovšek \& Petrič 2002). This indicates that in wet periods with intensive precipitation infiltrated rain and the contaminants dissolved in it pass fast through the vadose zone of karst aquifer and further towards the springs.

Measured concentrations of uranine at the Globočec spring were only slightly above the detection limit, but the signal was simultaneous to the one at the other springs (Fig. 9). We can conclude that additional to the main direction of flow towards the springs near Dvor at the existing conditions of high waters also the secondary connection with the Globočec spring was confirmed. Increased concentrations of tracer were detected at Globočec also after later precipitation events, and the maximum value of $0.085 \mathrm{ppb}$ was measured only in October 2005 which is almost one year after the injection. So each more intensive precipitation event is pushing out the tracer stored in the less permeable parts of the karst water system. The observed appearance of tracer at the spring and its concentrations are in such extensive and heterogeneous system a great deal influenced also by hydrological conditions which differ significantly in time but also in space. Obtained information about longer retention time in the direction towards Globočec should be considered in the planning of monitoring of groundwater in the area of influence of the landfill.

In five months long period of more regular sampling from the injection of tracer in October 2004 till the end of February 2005 approximately a half of the total amount of injected tracer was detected at all springs. Along with 


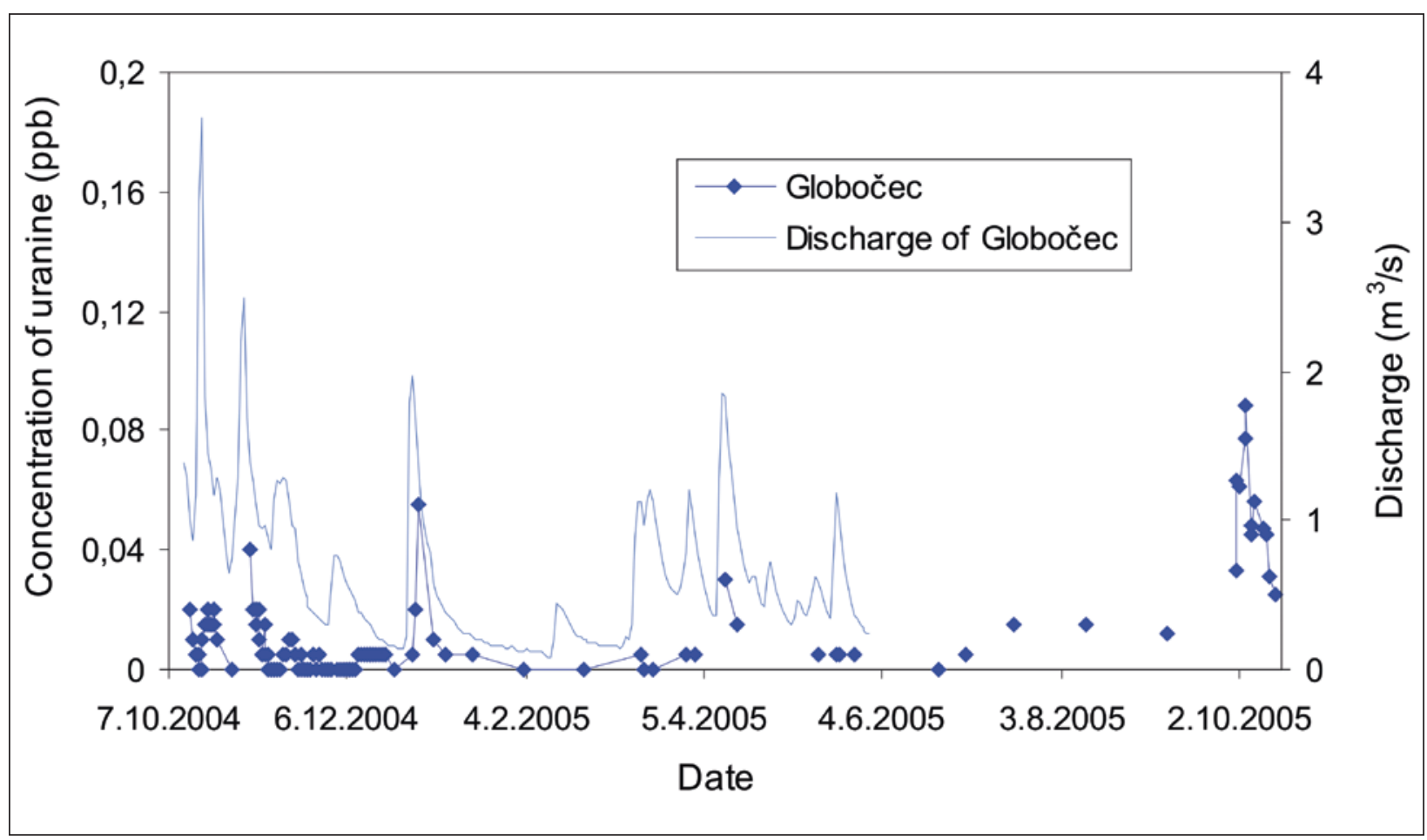

Fig. 9. Concentrations of uranine and discharges in the Globočec spring.

Sl. 9. Koncentracije uranina in pretok v izviru Globočec.

this result we should emphasise that the quality of discharge data applied in calculations was not very high and that several estimations and indirect comparisons were used as described in one of the previous chapters.
As the Globečec spring is captured for the water supply, the share of recovered tracer was estimated also for this spring. In one year around $3 \%$ of the injected uranine has been recovered there.

\section{CONCLUSIONS}

Performed tracer test with the injection of $7 \mathrm{~kg}$ of uranine in a highly-permeable vertical fissure at the margin of the Mala gora landfill during high waters in October 2004 confirmed the main groundwater connection with the springs Tominčev studenec, Javornikov izvir, Debeljakov izvir and Šica-Dvor in the Krka valley. In lower concentrations the tracer was detected in the Podpeška jama and Kompoljska jama Caves, and also a secondary direction of underground water flow towards the Šica near Mala Račna spring and both Krka springs was proved.

Special attention was dedicated to the Globočec spring as a main source of water supply in the Suha krajina region. Based on the results of tracer tests we can conclude that groundwater from the landfill area flows during high waters towards Globočec also, but this spring is mainly recharged from other parts of the karst aquifer.

Apparent dominant flow velocity in the main direction towards the springs near Dvor was approximately
$4 \mathrm{~cm} / \mathrm{s}$. Comparable velocities obtained by tracing of the Tržiščica sinking stream at medium waters in April 2000 indicate that at high waters with intensive precipitation before and after injection transport of tracer is not hindered even in a thicker vadose zone. At the time of injection the karst system was filled with water and in such conditions also the transport of tracer through the vadose zone is fast. Similar results were obtained by the tracer test through approximately one hundred meters thick vadose zone above the Postojnska jama Cave (Kogovšek 2000). This indicates very high vulnerability and a serious danger of pollution with harmful substances from the landfill. Then in the following period of one year the increase of the concentration of tracer was detected after each more intensive precipitation event. Although a part of a soluble tracer flows rapidly through the primary drainage paths, the remainder is retained in the vadose zone and is pushed out by newly 
infiltrated water in the following precipitation events over a long time period.

Some valuable information for the proper planning of the monitoring of groundwater were obtained by performed tracer test. A decision was made which springs should be included into the monitoring. As the main monitoring points Tominčev studenec and Globočec were suggested, but additionally also Javornikov izvir could be observed because the influences from the landfill are more intensive there (significantly higher concentration of tracer in a first peak than at other springs). The time and frequency of the sampling should be adjusted to hydrological conditions also, because the pollution signal can be expected at monitoring points after more intensive precipitation events.

\section{ACKNOWLEDGEMENT}

For co-operation in the preparative arrangements we would like to thank Andrej Juren (GeoSi d.o.o., Geological Institute). The tracer test was supported by the Institute of Mining, Geology and Geotechnology from Ljubljana, and by the public company Komunalna Rib- nica d.o.o. which is the manager of the Mala gora landfill. We would like to thank the Monitoring Office of the Environmental Agency of the Republic of Slovenia for giving us the data on measured water levels at the Globočec spring free of charge.

\section{REFERENCES}

Buser, S., 1968: Osnovna geološka karta SFRJ, list Ribnica 1:100000.- Zvezni geološki zavod, Beograd.

Gams, I., 1965: Aperçu sur l'hydrologie du karst Slovene et sus communications souterraines.- Naše jame, 7/1-2, 51-60, Ljubljana.

Genorio, R., 1999: Varovanje kraških vodnih virov, primer havarije plinskega olja v zajetju Globočec.Diplomska naloga, Ljubljana.

Grm, A. \& D. Novak, 1989: Vodne razmere na Dobrepolju in v Strugah.- Naše jame, 31, 15-25, Ljubljana.

Habič, P. \& A. Kranjc \& S. Svetličič, 1993: Študij kraških podzemeljskih vodnih povezav v Sloveniji (Poročilo za leto 1992).- Tipkano poročilo, IZRK, 8 str. + priloge, Postojna.

Kogovšek, J., 2000: Ugotavljanje načina pretakanja in prenosa snovi s sledilnim poskusom $\mathrm{v}$ naravnih razmerah.- Annales, 10/1, 133-142, Koper.

Kogovšek, J. \& M. Petrič, 2002: Podzemno raztekanje vode iz ponora Tržiščice (JV Slovenija).- Acta carsologica, 31/2, 75-91, Ljubljana.

Kogovšek, J. \& M. Petrič, 2004: Advantages of longerterm tracing - three case studies from Slovenia.- Environmental Geology, 47, 76-83, Berlin.
Kogovšek, J. \& M. Petrič \& M. Pregl, 2005: Preparation of the water quality plan for monitoring the impact area of the Mala gora landfill near Ribnica (SE Slovenia).- In: Stevanović, Z. \& P.T. Milanović (Eds), Water resources and environmental problems in karst : proceedings of the International conference and field seminars, Belgrade and Kotor, 13-19 September 2005. Institute of Hydrogeology, Faculty of Mining and Geology, 169-174, Belgrade.

Kolbezen, M. \& J. Pristov, 1998: Površinski vodotoki in vodna bilanca Slovenije.- MOP-Hidrometeorološki zavod Republike Slovenije, p. 98, Ljubljana.

Kranjc, A., 1981: Prispevek k poznavanju razvoja krasa v Ribniški Mali gori.- Acta carsologica, 9, 31-85, Ljubljana.

Novak, D., 1985: Izvir Globočec in njegovo zaledje.- Naše jame, 27, 5-9, Ljubljana.

Novak, D., 1987: Podzemni vodni tokovi na Dolenjskem.Dolenjski kras, 2, 23-27, Novo mesto.

Novak, D., 1992: Tominčev studenec pri dvoru in njegovo zaledje.- Naše jame, 33, 63-73, Ljubljana.

Šerko, A., 1946: Barvanje ponikalnic v Sloveniji.- Geografski vestnik, 18, 125-139, Ljubljana. 


\section{SLEDILNI POSKUS NA ODLAGALIŠČU MALA GORA PRI RIBNICI V JUGOVZHODNI SLOVENIJI}

\section{POVZETEK}

V zadnjem času je bilo opravljenih več sledilnih poskusov z odlagališč na slovenskem krasu z namenom, da bi bolje razumeli smeri in značilnosti odtekanja podzemne vode $\mathrm{z}$ območja teh virov onesnaževanja in pripravili učinkovit program za monitoring kakovosti podzemnih vod na vplivnem območju odlagališč. V oktobru 2004 smo poskus izvedli na odlagališču Mala gora pri Ribnici. Širše območje odlagališča je del kraške planote Male gore in Suhe Krajine, ki se na severovzhodni strani dviga nad dolino reke Krke, na jugozahodni pa nad Ribniško polje. Gradijo jo dobro prepustne jurske in kredne karbonatne kamnine (Sl. 1). Voda se pretaka podzemno proti številnim izvirom na obrobju. Največji so izviri v dolini Krke z njenima glavnima izvirom Krško jamo in Poltarico s skupnim srednjim pretokom $8,3 \mathrm{~m}^{3} / \mathrm{s}$. Izvir Globočec s srednjim pretokom med 1 in $1,5 \mathrm{~m}^{3} / \mathrm{s}$ je zajet za vodooskrbo Suhe Krajine (Sl. 2). Južno od Žužemberka pri naselju Dvor so še štirje večji izviri. Največji je Tominčev studenec s srednjim pretokom okrog $1,6 \mathrm{~m}^{3} / \mathrm{s}$ (Sl. 3). Poleg njega je prav tako stalen Debeljakov izvir, Javornikov izvir in Šica pri Dvoru pa sta aktivna samo ob visokem vodostaju. Na suhem kraškem polju Dobrepolje sta izvira iz Podpeške in Kompoljske jame aktivna po močnejšem deževju, drugače pa je stalen vodni tok v obeh jamah okrog $7 \mathrm{~m}$ pod dnom polja. Na južnem robu Radenskega polja izvira Šica pri Mali Račni, ponika pa na vzhodnem robu polja $\mathrm{v}$ Zatočno jamo.

$\mathrm{V}$ preteklosti je bilo na tem območju opravljenih več sledilnih poskusov (Sl. 1). V vseh primerih je bilo sledilo injicirano v ponikalnico. Za odlagališče pa je značilna razpršena infiltracija padavin in $\mathrm{v}$ njih raztopljenih škodljivih snovi v vadozno cono. Ker je debelina te cone okrog sto metrov, lahko precejanje skoznjo značilno vpliva na transport sledila in po analogiji tudi na transport in zadrževanje kontaminantov $\mathrm{v}$ kraškem podzemlju. Zato smo v poskusu na Mali gori za injiciranje sledila na površju izbrali dobro prepustno razpoko na obrobju odlagališča.

Po večdnevnem dežju smo 14. oktobra 2004 injicirali raztopino $7 \mathrm{~kg}$ uranina in jo zalili z $9 \mathrm{~m}^{3}$ vode iz cisterne (Sl. 5). Zaradi intenzivnih padavin $\mathrm{v}$ naslednjih dneh so pretoki izvirov zelo narasli in dosegli zelo visok vodostaj (Sl. 4). Vzorčenje smo organizirali na 11 lokacijah, pogostnost zajemanja na njih pa je bila različna. Fluorescenco smo merili v laboratoriju $\mathrm{z}$ luminiscenčnim spektrometrom LS 30, Perkin Elmer, vzorce pa smo predhodno dekantirali in po potrebi še filtrirali.
Uranin se je že po 5 dneh in $\mathrm{v}$ najvišjih koncentracijah do 1,18 ppb pojavil v Javornikovem izviru in Šici pri Dvoru (Sl. 6), hkrati pa tudi v Tominčevem studencu in nekoliko kasneje v Debeljakovem izviru (Sl. 7). Velike oscilacije koncentracije sledila v Podpeški jami kažejo na prepletanje dotokov iz različnih delov zaledja. Potrjena je bila tudi povezava s Kompoljsko jamo, vendar je bilo vzorcev premalo za bolj natančno analizo. Dokazano je bilo še odtekanje proti obema izviroma Krke in Šici pri Mali Račni (Sl. 8). Na vseh izvirih so se koncentracije uranina povečale po vsakem močnejšem padavinskem dogodku, ki je spiral zaostalo sledilo iz vadozne cone in kraških kanalov. Relativno visoke vrednosti so bile izmerjene v oktobru 2005 skoraj eno leto po injiciranju in podobne pojave je bilo možno pričakovati tudi $\mathrm{v}$ naslednjem obdobju. Izračunane navidezne dominantne hitrosti toka okrog $4 \mathrm{~cm} / \mathrm{s}$ so primerljive $\mathrm{z}$ rezultati sledenja Tržiščice v aprilu $2000 \mathrm{ob}$ srednjem vodostaju. Sklepamo lahko, da v namočenih obdobjih $\mathrm{z}$ intenzivnimi padavinami infiltrirana voda in $\mathrm{v}$ njej raztopljene škodljive snovi zelo hitro preidejo vadozno cono in odtekajo po kraških kanalih naprej proti izvirom. To kaže na zelo ranljiv vodonosnik in resno nevarnost njegovega onesnaženja s kontaminanti z odlagališča.

Posebno pozornost smo posvetili izviru Globočec, ki je zajet za vodooskrbo. Izmerjene koncentracije sledila so bile le malo nad mejo detekcije, vendar je bila oblika signala podobna kot pri drugih izvirih (Sl. 9). Maksimalna vrednost je bila dosežena šele v oktobru 2005. Sklepamo lahko, da izvir Globočec napajajo predvsem podzemne vode iz drugih delov kraškega vodonosnika, vendar ob visokem vodostaju proti njemu odtekajo tudi vode z območja odlagališča.

Ocena deleža povrnjenega sledila je zaradi slabše kakovosti podatkov o pretokih le približna. $\mathrm{V}$ času od začetka poskusa v oktobru 2004 do konca februarja 2005 je skozi izvire iztekla približno polovica injiciranega sledila, od tega skozi Globočec okrog 3\%.

$\mathrm{Na}$ osnovi zbranih rezultatov je bil izdelan program monitoringa. Kot glavni točki opazovanja sta bila predlagana izvira Tominčev studenec in Globočec, dodatno pa še Javornikov izvir, saj se je vpliv z odlagališča tam pokazal najbolj izrazito (značilno višje koncentracije sledila kot v drugih izvirih). Čas in frekvenco vzorčenja je potrebno prilagoditi hidrološkim razmeram, saj lahko signal onesnaženja pričakujemo po močnejših padavinah. 
